\title{
МОНГОЛ УЛС НЭГДСЭН ҮНДЭСТНИЙ БАЙГУУЛЛАГЫН ГИШУУН БОЛСОН НЬ. ТУУНИЙ ТУУХЭН АЧ ХОЛБОГДОЛ
}

\author{
ШУА-ийн Олон улс судлальн \\ хүрээлэнгийн захирал, НУБ-ыл дэмжих \\ Монголын нийгэмлэгийн тэргүун, \\ ШУ-ны доктор, профессор Лувсангийн Хайсандай
}

\begin{abstract}
Эрхэм номын андууд аа!
Эрхэмсэг хатагтай, ноёд оо! Та бүхний энэ өдрийн амар амгаланг айлгая.
\end{abstract}

Нэгэн ухаантан өгүүлсэн нь: “Өчигдрийг мартаж болохгүй, яагаад гэвэл тэр нь өнөөдрийн ч маргаашийн ч багш! ” гэсэн байдаг. Түүн лүгээ адил өнгөрсөн, одоо, ирээдүй гэсэн гурван их цагийн эргэлт, тэдгээрийн хоорондын нягт уялдаа холбоо, харилцан шүтэлцээнд нь алив нэгэн түүхэн үйл явдлын өрнөл буурлыг, ямарваа улс гүрний түүхт замналыг ул үндэстэй, буурь суурьтай авч үзвээс жинхэнэ шинжлэх ухааны зөв аргазүй болдог бөлгөө. ЧухамхүҮ энэ л үүднээс манай улсын НҮБ-д элсэн орсон түүхэн үнэнийг бодитой алсын хараатай судлан шинжилж, нэгтгэн дүгнэх шаардлагатай. Энэ утгаар авч үзэхүл, манай улсын НҮБ-д гишүүнээр элсэн орсон зам тийм ч дардан шулуун байсангүй. 1946 оны зургаадугаар сарын 21-ны өдөр Бүгд Найрамдах Монгол Ард улсын засгийн газар өөрийн улсыг Нэгдсэн Үндэстний Байгууллагын гишүүнээр элсүүлэн авахыг хүссэн илгээлтийг тус Байгууллагын тэр үеийн Ерөнхий нарийн бичгийн даргын нэр дээр явуулсан байдаг.

НҮБ-ын нарийн бичгийн дарга нарын газар БНМАУ-ын өргөдлийг 1946 оны 6-р сарын 24-нд хүлээн авч, мөн сарын 27-нд хэвлэлд нийтэлж, Аюулгүйн Зөвлөлийн шинэ гишүүн элсүүлэх асуудал эрхэлсэн комисс 1946 оны 8-р сарын 6-нд авч хэлэлцээд, 8-р сарын 12-ны А3-ийн хаалттай хуралдаанаас Монголын тухай нэмэлт материал шаардлагатай хэмээн үзэж, хариу авах таван асуулт гаргаж, төлөөлөгчөө ирүүлэхийг манай Засгийн газарт хүсэлт болгожээ. /Хронологическая таблица рассмотрения заявления МНР в ООН. Архив МИД МНР. Ф. 61. Оп.2. Д.2. Л. 1 - 30 /

"НҮБ-ын Аюулгүйн Зөвлөлийн байнгын гишүүн 5 улс, байнгын бус 6 улсын /1965 оноос 10 улс болсон/ төлөөлөгчид оролцсон шинэ гишүүн элсүүлэх асуудлыг хэлэлцдэг 
хорооны ээлжит хуралдаан 1946 оны зургадугаар сарын 28-ны Даваа гаригт хуралдаад тэрхүҮ хуралдаанаас БНМАУ-ын тухай мэдээлэл авах нь зүйтэй гэж үзсэн. Тэр үед НҮБ-ын Ерөнхий нарийн бичгийн даргын туслах байсан Аркадий Соболев /3ХУ-ын/ 1946 оны долдугаар сарын 31-нд Улаанбаатарт цахилгаан утас илгээж Монголын Засгийн газар эрх бүхий төлөөлөгчдөө томилон Нью-Йоркт ирүүлэх ба таван асуудалд тодорхой хариулт өгөхийг уламжлан хүссэн байдаг.

БНМАУ-ын Засгийн газарт тавьсан таван асуудал гэвэл:

1. Монгол Улсын гадаад харилцааны цар хүрээ, түүний дотор улс төр, эдийн засаг, нийгэм, соёлын харилцааны эдүгээгийн дүр төрх ямар байгаа;

2. Монголын Засгийн газрын зүгээс гадаад харилцаагаа хөгжүүлэх, тухайлбал дипломат болон консулын төлөөлөгчдийг солилцох талаар баримталж буй бодлого, байр суурь;

3. Зөвлөлт Холбоот Улс, Хятад Улсаас гадна өөр ямар улс БНМАУ - тай дипломат болон консулын харилцаа тогтоох санал одоогоор тавиад байгаа, түүнд ямар хариу өгсөн бэ?

4. БНМАУ-ын Үндсэн хууль, засгийн тогтолцоо, түүний гадаад харилцаатай холбогдох бусад мэдээлэл;

5. Улсын төсөв, тухайлбал гадаад харилцаанд зориулж байгаа хөрөнгө зардал юу болох? Эдгээр болой.

ЗГ-ийн орлогч Ю. Цэдэнбал, Гадаад Хэргийн орлогч сайд Н. Лхамсүрэн, дипломатч

Б. Жаргалсайхан нар оролцсон манай төлөөлөгчид Нью-Иорк явах замдаа 8-р сарын 24-нд Парис дахь ЗХУ-ын ЭСЯ-аар дайрч В.М.Молотовтой уулзахдаа харуулж зөвлөгөө зааварчилгаа авсан байдаг. Тухайлбал: таван асуултын хоёрдахь асуулт нь: Монгол Улсын Засгийн Газар гадаад харилцаагаа хөгжүүлэх, дипломат болон консулын төлөөлөгчдөө солилцох тухайд ямар бодолтой байна вэ? хэмээн сонирхсон явдал байв. /ООН. Совет Безопасности. Официальные Отчёты, первый год, II сессия. Дополнение №4., 1946. С. 67- 68/

Гэтэл дээрх асуултын хариуг засварлахдаа: “БНМАУ хоёр хөрштэйгээ дипломат харилцаатай бөгөөд хэрэв шаардлага урган гарвал бусад улс орнуудтай дипломат болон консулын төлөөлөгчдөө солилцох, дипломат харилцаа тогтооход бэлэн байна” хэмээн өөрчилжээ. 
НҮБ-д элсэх өргөдлөө өгсөн найман улсыг: Албани, БНМАУ, Афганистан, Трансиордан, Эйре /Ирланд/, Португали, Испани, Щведийг 1946 оны 7-р сард АНУ-ын төлөөлөгч Жонсон “Дэлхийн бүх улсын хүчийг нэгтгэх шаардлагын дагуу” нэгэн зэрэг элсүүлэн авах санал оруулсан юм.

/Заседание Комиссии СБ по вопросу о приёме новых членов. Нью-Йорк, 31 июля 1946г. Архив МИД МНР. Ф9. Оп. 2. Д. 1. Л. 6-7/

Гэтэл энэхүҮ саналыг ЗХУ-ын төлөөлөгч А.А.Громыко эсэргүүцэж улмаар А3 өргөдөл өгсөн улсуудыг өргөдөл өгсөн он сарын дарааллаар нэг бүрчлэн хэлэлцэх болсноор БНМАУ энэхүҮ боломжийг алдсан юм.

1947 оны наймдугаар сарын 18-нд НҮБ-ын Аюулгүйн Зөвлөлийн 186 дугаар хуралдаанд Монгол Улсын хүсэлтийг дахин хэлэлцжээ.

Өнгөрсөн жилийн нь хуралдаан дээр Монгол Улсыг НҮБ-ын гишүүнээр элсүүлэхэд татгалзаж чадаагүй Гоминданы Хятадын төлөөлөгч Цзян Тинфу үг хэлэхдээ, Монголын цэрэг энэ оны зургадугаар сард манай улсын хилд цөмрөн орж Бейташан нэртэй газарт хүрчээ. Пейташан нь хуучин засгийн хилийн дээсээс дотогш 100 гяруй километрт оршдог болой Монголын тусгаар тогтнолыг хүлээн зөвшөөрөх үед тэрхүҮ хилийн дээсний талаар ямар ч буруу зөрүҮ маргаан байгаагүй юм. Гэтэл монголчууд зэвсгийн хүчээр Хятадым нутаг дэвсгэрт халдан довтолсон үеэс л асуудал гарч ирсэн юм. ИйнхүҮ манай нутагт цөмрөн орсон явдлыг нүүдэлчин олны төрөлхийн зөн авьяас гэж бодож болох юм л даа. Тэгэхдээ энэ нь яг тийм юм биш ээ. Яагаад гэвэл тэр цэргүүдийг ЗХУ-ын тэмдэг бүхий байлдааны хэд гурван нисэх онгоц дагалдан орж ирсэн юм.

Ийм учраас Монгол улс энхийг эрмэлзэх улс биш гэж үзэж НҮБ-д элсүүлэхэд би татгалзахаас өөр аргагүй бопж байна гэжээ.

Өрнөдийн орныхон Хятадын төлөөлөгчийн энэ байр суурийг дэмжсэн байдаг. Зөвлөлтийн төлөөлөгч А.Громыко Аюулгүйн Зөвлөлийн зарим гишүүдийн иймэрхүү нотолгоо нь ямар ч үндэсгүй бөгөөд бодит байдал, үнэн баримттай нийцэхгүй байна хэмээн няцаалт өгөөд, БНМАУ-ын хин дээр тухайлбал 6 дугаар сарын 9-нд болсон будлиан бол Монгопын талаас шалтгаалан үүссэн хэрэг явдал биш ээ. Үүнийг бодит баримт болон газрын зураг гэрчилж байна. Яагаад гэвэл Хятадын зүгээс горипж өрсөөд байгаа тэр хэсэг газар нутаг бол БНМАУ-ын нутаг дэвсгэрт хамаарах нь зөвхөн Монгол болон Зөвлөлтийн төдийгүй Хятадын мэдэлд буй газрын зураг дээрээс харваас тодорхой байгаа юмаа гэж цохон тэмдэглээд БНМАУ бол НҮБ- ын гишүүн байх Дүрмийн шаардлагыг хангасан улс бөгөөд хэрэв Аюулгүйн Зөвлөл уг асуудлаар эсрэг шийдвэр 
гаргавал буруутан болно гэжээ.

Ийнхүу хэлэлцээд санал хураалт болоход Польш, Сири, ЗХУ төлөө санал өгч, Хятад, Америк, Англи эсрэг санал өгөөд бусад гишүҮд түүний дотор Франц түдгэлзжээ. БНМАУ-ын шударга хүсэлт шаардлагыг хоёрдахь удаа ийнхүү хүлээж авсангүй ажээ.

1949 оны оны долдугаар сарын 20, 21-ний өдрүүдэд Аюулгүйн Зөвлөлийн хуралдаан дээр НҮБ-д гишүүнээр элсэхийг хүсч өргөдөл өргөн барьсан улс орон түүний дотор Албани, Болгар, Унгар, Монгол, Румыны асуудлыг хэлэлцжээ. АНУ-ын төлөөлөгч У.Р. Остин үг хэлэхдээ Болгар, Унгар, Румын улс Грек дэх партизануудад бүх талын тусламж дэмжлэг үзүүлж байна. Тэдгээр оронд хүний эрхийг бүдүүлгээр зөрчиж байна. Албани зэрэг дээрх орнууд НҮБ-ын дүрмийн шаардлагыг биелүүлж чадна гэдгийг нотлох лавтай мэдээлэл бидэнд алга байна гэжээ.

ЗХУ-ын төлөөлөгч С.К.Царапкин, Украины төлөөлөгч Д.З.Ману-ильский нар БНМАУ-ын эрх ашгийг хамгаалж, байр сууриа дахин тодорхой илэрхийлээд дээрх орнуудын өргөдлөө өгсөн дэс дарааллаар хэлэлцэж, харин санал хураалтыг улс тус бүрээр бус, багц бөөнөөр нь авч явуулах санал тавьжээ. Энэ санал дэмжигдсэнгүй.

Аюулгүйн Зөвлөлийн тус 445 дугаар хуралдаан дээр БНМАУ-ыг элсүүлэх асуудал хэлэлцээд санал хураахад ЗХУ, Украин хоёр элсүүлэхийн төлөө санал өгч, Канад, Хятад хоёр эсрэг санал, АНУ, Англи, Франц зэрэг улс түдгэлзэх санал өгсөн байна.

Тийнхүу Монгол улсын хүсэлтийг бараг жил дараалан хэлэлцсэн бөгөөд тухайн үед Аюулгүйн Зөвлөлийн гишүүн байсан янз бүрийн орнуудын байр суурь нааш цаашаа олонтаа өөрчлөгдөж байжээ.

Бүхэлд нь арван таван жилийн турш БНМАУ-ыг НҮБ-д элсүүлэхийг эсэргүүцсэн шалтгаануудыг АЗ-ийн Хуралдааны баримтуудаас түҮвэрлэн үзвэл, ҮҮнд: БНМАУ нь гадаад бодлоготой, дипломат бодлогын туршлага хуримтлуулаагүй, гадаад бодлого нь бие даасан бус байдалтай, ЗХУ-ын колони ба дагуул улс, дэлхийн хэмжээнд хүлээн зөвшөөрөгдөөгүй улс хэмээн шүүмжилсэн байдаг. Гэвч өнөөдрийн өндөрлөгөөс харвал энэ нь тухайн үеийн системтэй шууд холбоотой үүссэн нөхцөл байдал байсан нь тодорхой юм. Иймд БНМАУ-ыг НҮБ-д элсүүлэх асуудалд сөргөөр нөлөөлсөн нэгэн гол гадаад хүчин зүйлс нь “Хүйтэн дайн” байсан бөгөөд хоёр системийн хоорондын тэмцэл зөрчил нь НҮБ-ын тавцнаа шилжиж зөвхөн Монгол бус мөн өөр олон шинээр элсэх хүсэлтэй байсан орнуудын асуудлыг мухардалд оруулж ирсэн юм.

БНМАУ-ын гадаад харилцаа 1940-өөд оны эцэс, 50-иад оны эхнээс өргөжиж, БНХАУ, Дорнод Европын ардын ардчилсан улс орон, Вьетнам, Энэтхэг, Бирм, Индонез 
зэрэг улс оронтой дипломат харилцаа тогтоосон билээ. 1960-аад оны эхээр колонийн систем задран бутарч эхлэхэд Брунеи, Камбож, Куба, Балба, Мали, Алжир зэрэг Ази, Африк, Латин Америкийн 20 гаруй улстай дипломат харилцаатай болоод байлаа.

Тэр үед НҮБ-ын Ерөнхий Ассамблейн чуулганууд дээр манай улстай найрсаг харилцаатай орны төр, засгийн тэргүүн, тухайлбал Энэтхэгийн Ерөнхий сайд Жавахарлал Неру нарын зэрэг нэр хүндтэй анд нөхөд, БНМАУ-ыг НҮБ-ын гишүүнд элсэх эрхийг нь олон жилийн турш саад тотгор болж байгааг зэмлэн буруушааж түүхийн шударга бус явдлыг арилгах цаг хэдийнэ болсныг нэг бус удаа цохон тэмдэглэсээр байв.

Ер нь тэр үеэр Аюулгүйн Зөвлөл Ойрхи Дорнодын дайн, Унгарт гарсан үймээн, өмнөд Африк дахь аппартеидын бодлого, Конгод болсон хэрэг явдал зэрэг нарийн түвэгтэй асуудлыг тамтаггүй маргаантай хэлэлцэж ихээхэн цаг зарцуулж байжээ.

1960 онд Монгол улсыг элсүүлэх тухай ЗХУ-ын оруулсан тогтоолын төсөл, мөн саявтар. Өргөдөл өгсөн Мавританийг гишүүн болгох гэж Францын оруулсан тогтоолын төслийг хэлэлцээд бас шийдвэрлэж чадаагүй билээ. Тэр үед Мавританийг өөрийн нутаг дэвсгэрийн хэсэг хэмээн үзэж байсан Марокко уг асуудлыг хэлэлцэхийн эсрэг байсан. А3-ийн дотор ширүүн маргаан үүссэн байдаг. Эцэст нь Монгол, Мавританыг шийдвэрлэж чадаагүй юм.

Монгол улс бас нэгэн шинэ онтой золгож, олон сар өнгөрсний дараа НҮБ-ын гишүүн болох БНМАУ-ын хүсэл эрмэлзэл биелэгдэж 15 жилийн зүдэргээтэй байдлаас ангижрах цаг мөч иржээ.

1961 оны аравдугаар сарын 24-ний лхагва гаригийн үдээс хойш 971 дүгээр хуралдаанд Аюулгүйн Зөвлөл БНМАУ-ын хүсэлтийг арван гуравдахь удаад хэлэлцэв. Тэр өдөр мөн Мавритинийн асуудал байлаа. Аль орны тухай эхэпж хэлэлцэх талаар нэлээд маргалдсаны эцэст Монгол Улсыг НҮБ-д элсүүлэх асуудлыг эхлэн хэлэлцэх болсон юм.

ЗХУ-ын төлөөлөгч В.Зорин үг хэлж хэрэв БНМАУ-ыг элсүүлэх асуудлыг нааштай шийдвэрлэвэл Мавританийн хувьд бид хориг тавихгүй гэж мэдэгдсэн юм.

Тайваний төлөөлөгч Цзян Тинфу үг хэлж, байр сууриа илэрхийлээд бид санал хураалтад оролцохгүй, өөрөөр хэлбэл хориг тавих /вето/ эрхээ эдлэхгүй гэжээ.

АНУ, Англи, Францын төлөөлөгчид Монгол улсыг элсүүлэх асуудалд хориг тавихгүй гэж мэдэгдсэн билээ.

Аюулгүйн Зөвлөлийн тэр үеийн гишүүн байсан Либери, Нэгдсэн Араб, Турк, Цейлон /Шри Ланка/, Чили, Эквадорын төлөөлөгчид уг асуудлыг бүрэн дэмжих байр суурьтай байгаагаа илэрхийлжээ. 
Дараа нь Аюулгүйн Зөвлөлөөс гаргах S/4950 тоот тогтоолоор санал хураахад АНУ түдгэлзэж, /татгалзсан гишүүн үгүй/, бусад гишүүд төлөө санал өгчээ.

НҮБ-ын Ерөнхий Ассамблейн 1961 оны аравдугаар сарын 27-ны өдрийн хуралдаан дээр БНМАУ-ыг НҮБ-ын гишүүнд элсүүлэх тухай Аюулгүйн Зөвлөлийн дээрх тогтоолыг бүх гишүүн улсын нэрийг дуудах журмаар санал хураалт болж олонхийн саналаар баталсан байдаг.

Манай ГЯЯ-ны нэгдүгээр орлогч сайд, профессор Д.Цэвэгмид тэргүҮтэй, Б.Жаргалсайхан, Б.Дашцэрэн, О.Дамдиндорж, Б.Орсоо, Б.Ванчин-дорж нар оролцсон БНМАУ-ын төлөөлөгчид Аюулгүйн Зөвлөлийн тэрхүҮ хуралдаан, НҮБ-ын Ерөнхий Ассамблейн XVI чуулганд оролцсон билээ. 1962 оноос эхлэн манай улсын төлөөлөгч ЕА-ын бүх хуралдаанд оролцдог болсон.

Монгол улс 1961онд ийнхүү НҮБ-д элсэн орсноор тус улсын нэр хүнд олон улсын тавцанд нэмэгдэж, гадаад харилцаа нь өргөжин бэхжих болсон юм.

Тус байгууллагын хүрээнд Монгол Улс бусад орнуудтай харилцаа, хамтын ажиллагаагаа өргөжүүлэн бэхжүүлэхийн зэрэгцээ НҮБ-ын системийн бусад төрөлжсөн байгууллагуудтай хамтран ажиллах болсон юм. Өнгөрсөн хугацаанд Монгол Улс НҮБ болон түүний харьяа байгууллагуудаас санхүү, техник технологи болон мэргэжлийн асар их хэмжээний тусламж дэмжлэг авсан нь тус орны нийгэм, эдийн засгийн хөгжилд ихээхэн түлхэц өгсөн юм. Монгол Улсад 1963 оноос хойш 200 гаруй сая долларын техникийн болон буцалтгүй тусламж үзүүлсэн байна.

Монгол Улс НҮБ-ын үйл ажиллагаанд идэвхтэй хувь нэмэр оруулж ирсэн. Манай дипломатууд Ерөнхий Ассамблейн ээлжит, тусгай болон онцгой бүх чуулганд оролцож олон улсын асуудлаарх өөрийн орны засгийн газрын-бодлого, байр суурийг илэрхийлж тэдгээрийг шийдэхэд хувь нэмрээ оруулсаар ирсэн. Манай Улс НҮБ-д элсэн орсноос хойш янз бүрийн асуудлаар 50 гаруй тогтоол шийдвэр санаачлан батлуулж 500-аад тогтоол шийдвэрийг хамтран боловсруулсан байна.

Монгол Улсын санаачилсан НҮБ-ын тогтоол шийдвэрийн дотор "Зэвсэг хураах долоо хоног", "Ард түмний энх тайван амьдрах эрхийн тунхаг", хөгжиж буй орнуудын эдийн засаг, нийгмийн хөгжилд улсын хэвшил, хоршоод болон мэргэжилтэй боловсон хүчний гүйцэтгэх үүргийн тухай тогтоол, нийгэм эдийн засгийн суурь өөрчлөлтууд, хөдөөгийн эмэгтэйчүүдийн амьдралын түвшинг сайжруулах, бичиг үсэг үл мэдэх явдлыг арилгах олон улсын жил, олон улсын аюулгүй байдал ба Монгол Улсын цөмийн зэвсэггүй статус, далайд гарцгүй орнуудын бэрхшээлүүдийг даван туулах арга хэмжээ, энх тайван, хөгжил ба байгаль орчныг хамгаалах тухай тогтоолууд зэргийг дурдаж 
болно.

Монгол Улс НҮБ-д элссэнээс хойш Ерөнхий Ассамблейн дэд ерөнхийлөгчөөр 8 удаа, Ерөнхий Ассамблейн гол хороодын илтгэгч, дэд даргаар нийт 15 удаа сонгогджээ.

Монгол Улс Ерөнхий Ассамблейн чуулганд төрийн тэргүүний түвшинд 9 удаа оролцжээ. Үүнд Ю.Цэдэнбал(1967онд), Ерөнхийлөгч П.Очирбат (1992, 1995 онууд), Ерөнхийлөгч Н.Багабанди (2000 онд), Ерөнхийлөгч Н.Энхбаяр (2005 онд), Ерөнхий сайд С. Баяр (2007 онд), Ерөнхий сайд С. Батболд (2010 онд), Ерөнхийлөгч Ц. Элбэгдорж (2011 онд), тус бүр оролцжээ. Монгол Улс ба НҮБ-ын харилцаа, хамтын ажиллагааг бэхжүүлэх хүрээнд НҮБ-ын Ерөнхий нарийн бичгийн дарга нар (Курт Валдхейм 1977 онд, Перес де Кулляр 1987 онд, Кофи Аннан 2002 онд) манай оронд айлчилжээ. Энэ бүхэн бол НҮБ-д элсэн орсны идэвхитэй үйл ажиллагааны үр дүн мөн. 